\title{
PENGARUH LATIHAN BARBELL CURLS DAN TRICEPS PUSHDOWN TERHADAP HIPERTROFIOTOT-OTOT BAGIAN LENGAN ATAS PADA ANGGOTA MAX POWER GYM DAN AEROBIC KOTA PADANG
}

\author{
Galang Cikal Cakrawalad ${ }^{1}$, Apri Agus ${ }^{2}$ \\ Universitas Negeri Padang \\ galangcikal96@gmail.com
}

\begin{abstract}
The main problem for members of Max Power Gym \& Aerobic is that many of them have a variety of training targets such as goals for muscular hypertrophy and increasing physical conditions and other desired training targets, but they do not know how to practice the right principles for the target training, many who only do exercises with modest knowledge and complain of insignificant results against the desired training targets.

The research method used was quasi-experimental. The form of training that is focused on is barbell curls and triceps pushdown exercises using the pyramid training method. The population in this study is a member of Max Power Gym \& Aerobic as many as approximately 200 people. Before the study was conducted the planned number of samples were 20 samples that had target muscle hypertrophy exercises, the samples obtained were 14 samples that had target muscle hypertrophy exercises. The study began on March 25 to May 25 with the age range of the samples between 20 years - 29 years. The sampling technique is done by purposive sampling technique on members who have target muscle hypertrophy exercises. The data analysis technique used is the T test at the significant level $\alpha=0.05$.

Based on the results of the study from the $t$ test calculations obtained tcount (18)> ttable (2.16) for ttable at a significant level $\alpha=0.05$, the following conclusions can be drawn, there is a significant effect of barbell curls and triceps pushdown exercises on muscle hypertrophy - upper arm muscles in members of the Max Power Gym \& Aerobic City of Padang.
\end{abstract}

Keywords: Barbell Curls, Triceps Pushdown, Hypertrophy of the Muscles

\begin{abstract}
Abstrak
Permasalahan yang utama pada anggota Max Power Gym \& Aerobic adalah banyak dari mereka yang memiliki berbagai macam target latihan seperti tujuan untuk hipertrofi otot dan meningkatkan kodisi fisik dan target latihan lainnya yang diinginkan, tetapi mereka tidak mengetahui bagaimana prinsip latihan yang tepat untuk target latihan, banyak yang hanya melakukan latihan dengan pengetahuan seadanya dan mengeluhkan hasil yang kurang signifikan terhadap target latihan yang diinginkan.
\end{abstract}


Metode penelitian yang digunakan adalah experiment semu (quasi experiment). Bentuk latihan yang difokuskan adalah latihan barbell curls dan triceps pushdown dengan menggunakan metode latihan piramida.Populasi dalam penelitian ini adalah anggota Max Power Gym \& Aerobic sebanyak kurang lebih 200 orang.Sebelum penelitian dilakukan jumlah sampel yang direncanakan adalah sebanyak 20 sampel yang memiliki target latihan hipertrofi otot, sampel yang didapatkan 14 sampel yang memiliki target latihan hipertrofi otot. Penelitian dimulai pada tanggal 25 Maret -25 Mei dengan rentang umur para sampel adalah antara 20 tahun - 29 tahun. Teknik pengambilan sampel dilakukan dengan teknikpurposive samplingpada anggota yang memiliki target latihan hipertrofi otot.Teknik analisis data yang digunakan adalah uji $\mathrm{T}$ pada taraf signifikan $\alpha=0,05$.

Berdasarkan hasil penelitian dari perhitungan uji $t$ didapatkan thitung(18) > ttabel(2,16)untuk ttabel pada taraf signifikan $\alpha=0,05$, dapat diberikan kesimpulan sebagai berikut, terdapat pengaruh yang signifikan latihanbarbell curls dan triceps pushdown terhadap hipertrofi otot - otot bagian lengan ataspada anggota Max Power Gym \& Aerobic Kota Padang.

\section{Kata Kunci :Barbell Curls,Triceps Pushdown, Hipertrofi Otot-Otot PENDAHULUAN}

Olahraga menjadi hal yang sangat dibutuhkan oleh tubuh, yang mana salah satu fungsinya adalah menjaga dan meningkatkan kebugaran tubuh ataupun sebagai cara untuk menghindari atau rehabilitasi penyakit. Olahraga sendiri bisa dilakukan dimana saja, bisa dilakukan di luar ruangan ataupun di dalam ruangan yang mana dapat disesuaikan dengan kebutuhan masing masing individu.

Olahraga tentunya juga harus dilaksanakan harus mengikuti prinsip prinsip dari latihan dan disesuaikan dengan kemampuan tubuh, seperti yang dijelaskan dalam UU Republik Indonesia tahun 2005 NO. 3 Pasal 20 Ayat 5 tentang Sistem Keolahragaan Nasional bahwa“Untuk kemajuan prestasi pemerintah daerah dan / atau masyarakat dapat mengembangkan: (a) perkumpulan olahraga, (b) pusat penelitian dan pengetahuan, ilmu pengetehuan dan teknologi olahraga, (c) central pembinaan olahraga prestasi, (d) pendidikan dan pelatihan olahraga, (e) prasarana dan sarana olahraga prestasi, (f) sistem pemaduan dan pengembangan bakat olahraga, (g) sistem informasi keolahragaan dan melakukan uji coba keterampilan prestasi olahragawan pada tingkat daerah, nasional dan internasional sesuai dengan kebutuhan". 
Dengan berkembangnya teknologi saat ini, masyarakat sangat dipermudah untuk hal apapun, salah satunya dalam hal berolahraga.Pada zaman modern saat ini masyarakat tidak perlu berpanas-panas untuk berolahraga.Fitness centeradalah solusi untuk berolahraga yang tidak perlu bersusah payah dan berpanas - panas untuk melakukan olahraga, karena sudah banyak terdapat fasilitas - fasilitas olahraga yang sesuai dengan kebutuhan kita.Tujuan para anggotadi Max Power Gym \& Aerobic pastinya bermacam-macam, antara lain untuk menjaga kebugaran dan kesehatan tubuh, untuk menurunkan berat badan dan untuk menambah massa otot atau hipertrofi. Namun demikian, banyak dari anggota yang belum mengetahui prinsip-prinsip dasar latihan beban.

Permasalahan yang utama ketika penulis melakukan observasi dan melakukan wawancara pada anggota Max Power Gym \& Aerobic adalah banyak dari mereka yang memiliki tujuan untuk memiliki tubuh yang ideal dan atletis dan masih banyak lagi seperti ingin meningkatkan kodisi fisik dan masih banyak target latihan lainnya yang diinginkan, tetapi mereka tidak mengetahui bagaimana prinsip latihan yang tepat untuk target latihan mereka, banyak yang hanya melakukan latihan dengan pengetahuan seadanya dan mengeluhkan hasil yang kurang signifikan terhadap target latihan yang diinginkan. Maka dari itu penelitian ini dipilih salah satunya untuk mengetahui apakah latihan beban dengan metode Piramida terhadap Hipertrofi otot - otot bagian lengan atas anggota Max Power Gym \& Aerobic Kota Padang.

Prinsip - prinsip metode latihan sangat penting diketahui untuk tercapainya tujuan latihan yang diinginkan.Salah satu metode latihan yang paling efektif untuk hipertrofi otot adalah metode pyramid-set atau metode piramida.Karena intensitas latihan piramida adalah sub-maximal dan beban latihan bertambah di setiap setnya, sehingga memacu kinerja otot untuk bekerja lebih, sehingga terjadi perubahan bentuk dan volume otot.Maka dari itu metode yang efektif adalah metode latihan piramida.Akan tetapi beberapa anggota tidak mengetahui akan hal tersebut.

Bompa dalam Bafirmandan Apri Agus (2010: 15) latihan fisik merupakan "akrivitas olahraga secara sistematik dalam waktu yang lama, ditingkatkan 
secara progresif dan individual yang mengarah kepada ciri - ciri fungsi dan psikologis manusia untuk mencapai sasaran yang telah ditentukan.Melalui latihan fisik seseorang untuk mencapai tujuan tertentu.Dalam istilah fisiologisnya, seseorang mengejar tujuan perbaikan sistem organisme dan fungsinya untuk mengoptimalkan prestasi dan penampilan olahraganya".

Ada beberapa prinsip pada latihan kekuatan, menurut Bowers dan Fox dalam Sukadiyanto (2011:96) "bahwa prinsip beban lebih (overload), progresifitas, urutan latihan, dan spesifikasi”.Menurut Arnold Scwarzenegger dalam bukunya yang berjudul Encylopedia of Modern Bodybuilding (1985:122) bahwa“Latihan kekuatan yang berat akan menempatkan ketegangan yang luar biasa pada serat otot yang relatif sedikit pada satu waktu, yang mana menyebabkan terjadinya pembesaran dan penebalan pada otot (hiperthropi)".

Menurut Bowers dan Fox dalam Sukadiyanto (2011: 100) juga menjelaskan bahwa "Latihan kekuatan berpengaruh terhadap hyperthrofi otot, perubahan secara biokimia, perubahan komposisi otot, dan perubahan pada kelentukan. Dengan demikian respon fiisiologi dan dampak latihan kekuatan ditandai oleh adanya proses adaptasi pesyarafan otot, hyperthrofi otot (pembesaran), adaptasi sel - sel, daya tahan otot, adaptasi kardiovaskuler, perubahan secara biokimia, peruabahan komposisi otot, dan perubahan pada kelentukan".

Selanjutnya Nossek dalam Bafirman dan Apri Agus (2010: 55) memberikan gambaran tentang metode latihan beban, bahwa "untuk mengembangkan kekuatan, yaitu harus dilaksanakan secara berkesinambungan minimal selama dua bulan".Pelaksanaan meningkatkan beban dalam metode piramida ada beberapa cara yaitu Beban pertama submaksimal, kalau sudah mampu melaksanakan, kemudian dinaikkan beban $5 \%$ begitu juga seterusnya. Intensitas latihannya sendiri bisa dimulai dari $70 \%$ lalu ditingkatkan sampai $100 \%$ dari kemampuan maksimal.Bentuk - bentuk latihan beban yang akan di programkan dalam penelitian adalah Standing Barbell Curls, Preacher Curls, Triceps Pushdown, Pull Down, dan Bench Press. Bentuk - bentuk latihan tersebut semuanya menggunakan otot yang sinergis pada otot - otot bagian lengan atas. 
Hipertrofi otot adalah peningkatan ukuran dari sel -sel otot.Berbeda dari hiperplasia otot yang berarti pembentukan sel - sel otot baru.Rangsangan hipertrofi akibat pengaruh latihan fisik mengakibatkan segolongan rangsangan bisa meningkatkan volume sel - sel otot.Perubahan ini terjadi sebagai respon adaptif yang berfungsi meningkatkan kemampuan untuk membangkitkan tenaga atau menahan kelelahan dalam kondisi anaerobik.

Menurut Bafirman (2013:79) menjelaskan bahwa "Hipertrofi otot bisa ditingkatkan melalui latihan kekuatan dan latihan anaerobik yang berintensitas tinggi serta berdurasi pendek lainnya. Latihan anaerobik yang berdurasi panjang, berintensitas rendah secara umum tidak menghasilkan hipertrofi jaringan yang efektif, seperti atlet yang berfokus kepada daya tahan hanya meningkatkan penyimpanan lemak dan karbohidrat di dalam otot, seperti neovaskularisasi.Pada dasarnya perlu suplai asam amino yang cukup untuk menghasilkan hipertrofi otot".

\section{METODE PENELITIAN}

Metode penelitian yang digunakan adalah experiment semu (quat experiment).Populasi dalam penelitian ini adalah member fitness Max Power Gym \& Aerobic sebanyak kurang lebih 200 orang.Sebelum penelitian dilakukan jumlah sampel yang direncanakan adalah sebanyak 20 sampel, tetapi sampel yang didapatkan hanya sebanyak 14 sampel yang mana dikarenakan kondisi saat melakukan penelitian yang mana dimulai pada tanggal 25 Maret - 25 Mei terdapat 21 hari dalam bulan puasa yaitu pada tanggal 5 Mei - 25 Mei, karena itu sampel yang sanggup untuk melakukan penelitian hanya sebanyak 14 sampel dengan rentang umur para sampel adalah antara 20 tahun - 29 tahun. Teknik pengambilan sampel dilakukan dengan teknik Purposive sampling.Teknik analisis data yang digunakan adalah uji-t pada taraf signifikan $\alpha=0,05$.

Bentuk tes yang dilakukan adalah dengan menggunaka tes tes Arm Girth Measurement. Pendeskripsian data dan uji persyaratan analisis pengujian hipotesis dalam penelitian ini dapat diolah dengan menggunakan rumus uji$t$.Sebelum melakukan uji-t maka dilakukan uji normalitas data dengan menggunakan uji Lilliefors. 


\section{HASIL PENELITIAN DAN PEMBAHASAN}

\section{Hasil Penelitian}

a. Data awal (Pre - Test) pengukuran otot - otot lengan atas pada anggota Max Power Gym \& Aerobic Kota Padang.

Pada tes awal (Pre - Test) pengukuran otot - otot lengan atas menggunakan teknik pengukuran arm girth measurementdari 14 orang sampel, maka diperoleh skor tertinggi $36,9 \mathrm{~cm}$, skor terendah $30 \mathrm{~cm}$, rata rata (mean) 33,79 dan standar deviasi 2,49. Distribusi frekuensi dapat digambarkan dalam tabel berikut :

Tabel 3.Distribusi frekuensi data hasil tes awal (Pre - Test)

\begin{tabular}{|c|c|c|c|}
\hline No & Kelas Interval & Frekuensi Absolute & Frekuensi Relatif \\
\hline 1 & $30-32 \mathrm{~cm}$ & 6 & $42,9 \%$ \\
\hline 2 & $33-35 \mathrm{~cm}$ & 5 & $35,7 \%$ \\
\hline 3 & $36-38 \mathrm{~cm}$ & 3 & $21,43 \%$ \\
\hline & Jumlah & $\mathbf{1 4}$ & $\mathbf{1 0 0 \%}$ \\
\hline
\end{tabular}

b. Data akhir (Post - Test) pengukuran otot - otot lengan atas pada anggota Max Power Gym \& Aerobic Kota Padang.

Pada tes akhir (Post - Test)pengukuran otot - otot lengan atas dengan menggunakan teknik pengukuran arm girth measurement dari 14 orang sampel, maka diperoleh skor tertinggi $38 \mathrm{~cm}$, skor terendah $31 \mathrm{~cm}$, rata - rata (mean) 35,14 dan standar deviasi 2,57. Distribusi frekuensi dapat digambarkan dalam tabel berikut :

Tabel 4.Distribusi frekuensi data hasil tes akhir (Post - Test)

\begin{tabular}{|l|c|c|c|}
\hline No & Kelas Interval & Frekuensi Absolute & Frekuensi Relatif \\
\hline 1 & $31-33 \mathrm{~cm}$ & 6 & $42,9 \%$ \\
\hline 2 & $34-36 \mathrm{~cm}$ & 4 & $28,6 \%$ \\
\hline 3 & $37-39 \mathrm{~cm}$ & 4 & $28,6 \%$ \\
\hline & Jumlah & $\mathbf{1 4}$ & $\mathbf{1 0 0} \%$ \\
\hline
\end{tabular}

Hipotesis yang diajukan adalah Seberapa besarkah pengaruh latihan barbell curls dan triceps pushdown terhadap hipertrofi otot - otot bagian lengan 
ataspada anggota Max Power Gym \& Aerobic Kota Padang.

Tabel 12.Rangkuman Hasil Pengujian Hipotesis Data Penelitian

\begin{tabular}{|c|c|c|c|c|c|c|}
\hline Data & Rata-Rata & Sd & thitung & A & ttabel & Keterangan \\
\hline $\begin{array}{l}\text { Data Awal } \\
\text { (Pre - Test) }\end{array}$ & 33,79 & 2,49 & \multirow[b]{2}{*}{18} & \multirow[b]{2}{*}{0,05} & \multirow[b]{2}{*}{2,16} & \multirow{2}{*}{$\begin{array}{c}\operatorname{th}(18)> \\
\operatorname{tt}(2,16) \\
\text { Terdappat } \\
\text { Pengaruti Yang } \\
\text { Signifikan }\end{array}$} \\
\hline $\begin{array}{c}\text { Data Akhir } \\
\text { (Post - Test) }\end{array}$ & 35,14 & 2,57 & & & & \\
\hline
\end{tabular}

Berdasarkan penjelasan dari tabel diatasth(18) $>\operatorname{tt}(2,16)$ dapat disampaikan bahwa thitung lebih besar dari pada tabel, maka $\mathrm{H}_{\circ}$ ditolak dan $\mathrm{H}_{\mathrm{a}}$ diterima, terdapat pengaruh yang signifikan pemberian latihan barbell curls dan triceps pushdown terhadap hipertrofi otot - otot bagian lengan atas anggota Max Power Gym \& Aerobic Kota Padang.

\section{Pembahasan}

Tujuan para anggotadi Max Power Gym \& Aerobic pastinya bermacammacam, antara lain untuk menjaga kebugaran dan kesehatan tubuh, untuk menurunkan berat badan dan untuk menambah massa otot atau hipertrofi. Namun demikian, banyak dari anggota yang belum mengetahui prinsip-prinsip dasar latihan beban.Karena setiap tujuan latihan akan berbeda takaran intensitas latihan yang dibutuhkan. Untuk itu metode latihan sangat berpengaruh besar terhadap keberhasilan latihan.Banyak anggota yang menjalani latihan tanpa mengacu pada program latihan yang benar, mereka menjalankan program latihan dengan hanya sepengetahuan mereka saja. Banyak dari mereka yang mempunyai tujuan latihan yang sama, rata - rata tujuan latihan yang mereka inginkan adalah mempunyai bentuk tubuh yang ideal dan atletis.

Prinsip - prinsip metode latihan sangat penting diketahui untuk tercapainya tujuan latihan yang diinginkan.Salah satu metode latihan yang paling efektif untuk hipertrofi otot adalah metode pyramid-set atau metode piramida.Karena intensitas latihan piramida adalah sub-maximal dan beban latihan bertambah di setiap setnya, sehingga memacu kinerja otot untuk bekerja lebih, sehingga terjadi perubahan bentuk dan volume otot.Maka dari itu metode 
yang efektif adalah metode latihan piramida.Akan tetapi beberapa anggota tidak mengetahui akan hal tersebut.

Penelitian ini bermaksud untuk meneliti pengaruh latihan barbell curls dan triceps pushdown terhadap hipertrofi otot - otot bagian lengan atas anggota Max Power Gym \& Aerobic Kota Padang. Sebelum penelitian dilakukan jumlah sampel yang direncanakan adalah sebanyak 20 sampel, tetapi sampel yang didapatkan hanya sebanyak 14 sampel yang mana dikarenakan kondisi saat melakukan penelitian yang mana dimulai pada tanggal 25 Maret 25 Mei terdapat 21 hari dalam bulan puasa yaitu pada tanggal 5 Mei $-25 \mathrm{Mei}$, karena itu sampel yang sanggup untuk melakukan penelitian hanya sebanyak 14 sampel dengan rentang usia sampel pada 20 tahun -29 tahun.

Sebelum diberi perlakuan terhadap sampel, maka terlebih dahulu dilakukan tes awal (Pre - Test) dengan menggunakan tes utama menggunakan teknik pengukuran Arm Girth Measurement lalu tes menggunakan Skinfold Caliper pada bagian biceps dan triceps sebagai variabel intervening untuk melihat apakah latihan tersebut juga mempengaruhi ketebalan lemak pada bagian otot-otot lengan atas tersebut, setelah itu juga dilakukan pengukuran terhadap beban maksimal setiap sampel terhadap program latihan yang akan diberikan seperti pengukuran beban maksimal pada latihan Barbell Curls, Triceps Pushdown. Setelah didapatkan data awal tersebut maka sampel diberikan program latihan sesuai dengan kemampuannya masing-masing sesuai dengan intensitas beban latihan yang telah didapatkan, latihan dilakukan setiap 4 kali pertemuan dalam seminggu dan dilakukan selama 2 bulan, jadi latihan didapatkan sebanyak 36 kali pertemuan selama 2 bulan tersebut, setelah dilakukan perlakuan selama 2 bulan tersebut maka selanjutnya dilakukan tes akhir (Post - Test) yang sama dengan tes awal (Pre - Test).

Pada tes awal (Pre - Test) pengukuran otot-otot lengan atas menggunakan teknik pengukuranArm Girth Measurementdari 14 orang sampel, maka diperoleh skor tertinggi $36,9 \mathrm{~cm}$, skor terendah $30 \mathrm{~cm}$, rata - rata (mean) 33,79 dan standar deviasi 2,49. Pada tes akhir (Post - Test) dari 14 orang sampel, maka diperoleh skor tertinggi $38 \mathrm{~cm}$, skor terendah $31 \mathrm{~cm}$, rata - rata (mean) 35,14 dan standar deviasi 2,57. Didapatkan peningkatan persentase 
sebanyak 4\%, dari perhitungan hipotesis menggunakan uji t didapatkan thitung(18) > ttabel $(2,16)$ untuk ttabel pada taraf signifikan $\alpha=0,05$, dari data tersebut dapat dijelaskan bahwa $t_{\text {hitung }}$ lebih besar dari pada $t_{\text {tabel, }}$ maka $H_{\circ}$ ditolak dan $\mathrm{H}_{\mathrm{a}}$ diterima. Dapat disampaikan bahwa terdapat pengaruh yang signifikan pemberian latihan barbell curls dan triceps pushown terhadap hipertrofi otot - otot bagian lengan atas anggota Max Power Gym \& Aerobic Kota Padang.

Penelitian dilakukan untuk melihat seberapa pengaruh latihan terhadap hipertrofi otot-otot lengan atas, tetapi juga dilakukan pengukuran tambahan sebagai kontrol menggunakan skinfold caliper untuk melihat apakah hanya terjadi hipertrofi otot saja atau juga dipengaruhi oleh ketebalan lemak. Maka untuk variabel intervening pada tes awal (Pre - Test) menggunakan skinfold caliper bagian triceps dari 14 orang sampel, maka diperoleh skor tertinggi 20 $\mathrm{mm}$, skor terendah $5 \mathrm{~mm}$, rata - rata (mean) 11,29 dan standar deviasi 4,95.Pada tes akhir (Post - Test) skinfold caliper bagian triceps dari 14 orang sampel, maka diperoleh skor tertinggi $15 \mathrm{~mm}$, skor terendah $5 \mathrm{~mm}$, rata - rata (mean) 10,57 dan standar deviasi 4,13.Didapatkan penurunan persentase lemak $6,4 \%$.

Untuk variabel intervening pada tes awal (Pre - Test) menggunakanskinfold caliper bagian biceps dari 14 orang sampel, maka diperoleh skor tertinggi $10 \mathrm{~mm}$, skor terendah $4 \mathrm{~mm}$, rata - rata (mean) 5,5 dan standar deviasi 2,59. Pada tes akhir (Post - Test) skinfold caliper bagian biceps dari 14 orang sampel, maka diperoleh skor tertinggi $8 \mathrm{~mm}$, skor terendah $3 \mathrm{~mm}$, rata - rata (mean) 4,43 dan standar deviasi 1,09. Didapatkan penurunan persentase lemak $19,4 \%$.

Ilhamjaya (dalam Eko Sucipto, 2016: 114) menyatakan bahwa :"sebagaimana karbohidrat, lemak juga mempunyai bentuk dasar yang digunakan dalam tubuh, yaitu asam lemak.Lemak diperoleh dari diet yang dicerna, memroduksi asam lemak dan sebuah substansi yang disebut gliserol. Setelahasam lemak diabsorbsi melalui sel saluran cerna, selanjutnyaakan diubah menjadi trigliserida. Trigliserida terdiri atas $1 \mathrm{~mol}$ gliserol dan $3 \mathrm{~mol}$ asam lemak.Trigliserida dapat dipecah menjadi gliserol dan asam lemak.Asam 
lemak disimpan sebagai trigliserida.Simpanan trigliserida ditemukan dalam jaringan lemak dan di dalam sel otot rangka.Ketika dibutuhkan oleh otot, asam lemak dari jaringan lemak dilepaskan dari trigliserida dan menuju otot melalui darah.Mobilisasi asam lemak dari cadangan lemak tubuh ke otot merupakan suatu hal penting untuk mengurangi berat badan melalui pembuangan lemak tubuh."

Dilansir dari situs jurnal.uny.id, penelitian yang dimuat Jurnal Keolahragaan Volume 4 mengungkapkan bahwa :"Ada dua bentuk utama dari bahan bakar yang disediakan untuk otot selama latihan, yang pertama adalah asam lemak yang ditransportasi melalui darah dari jaringan lemak, dan simpanan trigliserida yang terdapat di dalam sel otot sendiri.Dalam melakukan aktivitas fisik dibutuhkan energi yang berasal dari pembakaran karbohidrat, lemak, dan protein yang disesuaikan dengan tipe kerja otot dan intensitas latihan.Pembakaran karbohidrat sebagai sumber energi digunakan pada aktivitas yang berat dengan jangka waktu latihan yang pendek, sedangkan pembakaran lemak sebagai sumber energi digunakan untuk aktivitas atau latihan yang berat dengan jangka waktu yang lama." (Eko Sucipto, 2016: 115)

Dari hasil analisis yang telah dijabarkan dapat diambil kesimpulan bahwa apabila latihan barbell curls dan triceps pushdown dilakukan dengan benar dan pemberian intensitas latihan yang tepat secara berkelanjutan dan mengikuti prinsip - prinsip latihan kekuatan yang benar maka dapat terjadi hipertrofi yang signifikan pada otot - otot bagian lengan atas seseorang dan juga diiringi dengan terjadinya penuruan ketebalan lemak pada bagian tersebut atau juga bisa dinyatakan seiring terjadinya hipertrofi otot maka lemak pada bagian otot tersebut juga terjadi penurunan. Penerapan program latihan yang kurang terencana akan mengakibatkan target latihan yang ingin dicapai tidak akan maksimal.

\section{KESIMPULAN}

Berdasarkan analisis data dan pembahasan, maka dapat dikemukakan kesimpulan pada tes pengukuran otot-otot bagian lengan atas menggunakan teknik pengukuran arm girth measurement didapatkan data awal (Pre - Test) dengan rata - rata $33,79 \mathrm{~cm}$, lalu pada tes akhir (Post - Test) dengan rata - 
rata $35,14 \mathrm{~cm}$, maka didapatkan peningkatan persentase $4 \%$, sedangkan dari perhitungan uji t didapatkan thitung(18) > ttabel(2,16)untuk ttabel pada taraf signifikan $\alpha=0,05$. Setelah itu dapat dikemukakan kesimpulan sebagai berikut "Terdapat pengaruh yang signifikan pada latihanbarbell curls dan triceps pushdown terhadap hipertrofi otot - otot bagian lengan ataspada anggota Max Power Gym \& Aerobic Kota Padang".

\section{SARAN}

1. Kepada instruktur agar dapat memberikan program latihan yang tepat untuk tiap-tiap anggota yang memiliki target latihan yang berbeda-beda, agar target latihan dapat tercapai dengan signifikan.

2. Para anggota diharapkan berlatih dengan instruktur atau orang yang berkompeten dibidangnya dan lebih berhati - hati dalam melakukan teknik dalam latihan, apalagi jika intensitas beban latihan yang berat harus didampingi dengan orang yang paham dengan latihan tersebut.

3. Pada penelitian berikutnya diharapkan dapat menemukan program yang lebih berhubungan kepada gizi atau nutrisi yang tepat untuk hipertrofi dan lebih melengkapi kekurangan dalam penelitian ini.

\section{DAFTAR RUJUKA}

Agus, Apri. 2012. "Olahraga Kebugaran Jasmani". Padang : Sukabina Press

Bafirman, Apri Agus. 2010. "Pembentukan Kondisi Fisik". Padang : Wineka Media

Bafirman. 2013. " Fisiologi Olahraga”. Padang : Wineka Media

Barlian, Eri. 2016. “Metodologi Penelitian". Padang : Sukabina Press

Clarke, Harrison. 2010. "Application of Measurement to Health and Physical Education". USA

Corbin, Charles B., et al. 2013. "Concepts of Physical Fitness". Mc Graw Hill : NY

Heyward, Vivian. 2012. "Advance Fitness Assessment and Exercise Prescription". University of New Mexico

Kardiawan, Kadek Happy. "Pembentukan dan Pembinaan Kondisi Fisik".Yogyakarta : Graha IImu

Morrow, James. 2012. "Measurement and Evalutaion in Human Performance"

Schwarzenegger, Arnold. 1985. "Encyclopedia of Modern Body Building". NY: Simon and Schuster 
Sukadiyanto. 2011. "Pengantar Teori dan Metodologi Melatih Fisik". Bandung : Lubuk Agung

Supardi, dkk."Buku Ajar Anatomi Bagian Pertama".Padang : FIK UNP Syafruddin. 1999. "Dasar - dasar Kepelatihan Olahraga". Padang : FIK UNP UU RI No. 3. 2005. "Sistem Keolahragaan Nasional". Bandung : Fokusindo Mandiri

http://journal.uny.ac.id/index.php/jolahraga 